\title{
Firefighters: Psychopathology and working conditions
}

\author{
Bombeiros: psicopatologia e \\ condições de trabalho
}

\author{
Janine Kieling MONTEIRO \\ Daniel $\mathbf{A B S}^{1}$ \\ Ivete Dörr LABRES \\ Daiane MAUS \\ Thaís PIONER ${ }^{1}$
}

\begin{abstract}
Firefighters perform all kinds of rescues. Their job places them in potentially traumatic situations which may cause work-related mental disorders. This study aimed to investigate the working conditions and mental health of firefighters in Southern Brazil. The research subjects included 25 men and 2 women. The authors analyzed the anxiety, depression, alcohol use, post-traumatic stress disorder, and work environment of the firefighters, by means of scales, a questionnaire and an interview. Descriptive analysis and correlation measures were used, based on the variables of interest and content analysis. The results indicated that these professionals need higher salaries, better equipment and more training. Personal valorization and conversations with superiors were cited as positive aspects. Regarding the main aim of the study, the authors found correlations between alcohol abuse and length of service, alcohol abuse and age, and depression and age. These data suggested that there is emotional wear related to the profession, and the need of psychological support.
\end{abstract}

Uniterms: Firefighters; Mental health; Psychopathology; Work; Working conditions.

\section{Resumo}

O bombeiro realiza todo tipo de salvamento, o que coloca esse trabalhador em situações potencialmente traumáticas que podem ocasionar transtornos mentais associados ao trabalho. O objetivo desta pesquisa foi investigar as condições de trabalho e a saúde mental dos bombeiros, no sul do Brasil. Houve a participação de 25 homens e duas mulheres. Foram avaliados ansiedade, depressão, uso de álcool, Transtorno de Estresse Pós-Traumático e condições de trabalho, por meio de escalas, questionários e entrevista. Utilizaram-se análises descritivas e de medidas correlacionais entre variáveis de interesse e análise de conteúdo. Os resultados indicaram necessidades de melhorias no salário, equipamentos e treinamento. A valorização pessoal e diálogo com superiores foram citados como pontos positivos. Quanto ao objetivo principal, foram encontradas correlações entre consumo de álcool e tempo de serviço, uso desta substância e idade e entre depressão e idade. Estes dados sugerem um desgaste emocional associado à atividade profissional e a necessidade de apoio psicológico.

Unitermos: Bombeiros; Saúde mental; Psicopatologia; Trabalho; Condições de trabalho.

$\nabla \nabla \nabla \nabla$

1 Universidade do Vale do Rio dos Sinos, Programa de Pós-Graduação em Psicologia. Av. Unisinos, 950, Cristo Rei, 93022-000, São Leopoldo, RS, Brasil. Correspondência para/Correspondence to: J.K. MONTEIRO. E-mail: <janinekm@terra.com.br>.

Support: Conselho Nacional de Desenvolvimento Científico e Tecnológico, Process number 400950/2007-3. 
The occupation of firefighter involves frequent exposure to stressful events such as combating fires and rescuing victims, administering first aid, rescuing people in traffic accidents situation, land and water rescues, assistance in disaster situations, and rescues at height, among others. This repeated exposure to challenging and sometimes traumatic events, resulting from the firefighter's work itself, puts this professional at an increased risk of developing mental disorders including Post-traumatic Stress Disorder (PTSD) or symptoms of depression and anxiety. The main aim of this study was to investigate the working conditions and their association with the mental health of firefighters working in the Vale do Rio dos Sinos Region (RS) Brazil. This study was also based on an intervention in the health of these workers, previously developed together with this corporation (Monteiro et al., 2007).

\section{Mental health and work}

The occupational health area studies the workhealth relationship, in its socio-historical, political and economic aspects and in the analysis of collective and individual work (Minayo-Gomez \& Thedim-Costa, 1997). It conceives the worker as an active subject in the health and illness process, with effective participation in health activities. In the field of mental health and work, Le Guillant was the first author to seek the relationship between the social aspects of objective and subjective work conditions and clinical facts, in an attempt to find possible determinant factors for mental illness in this context (Codo, Soratto \& Vasques-Menezes, 2004).

According to Lima (2003), there is evidence to indicate that the practice of certain professions exposes individuals to elements harmful to their mental health. The author gives the example of a study which found a high frequency of cases of alcoholism and posttraumatic stress disorders, with or without depression, in military police officers. It also mentions that the action of the psychologist should be aimed at identifying these harmful elements and at the adoption of preventive measures in the workplace.

The organization of work contains biopsychosocial aspects that can be determinants in the manifestations of the health-illness process of workers (Mendes, 2007). However, it is essential to highlight that the work can simultaneously trigger experiences of distress and pleasure. Therefore, it appears that health and disease are not in isolation, but rather parts of a multidetermined process. The experience of pleasure or distress associated with work will depend on the mediation between the subjectivity of workers and the working conditions (Mendes \& Morrone, 2002). Some aspects that should be considered within the work organization are: the work activities (prescribed and actual); the work processes such as control, rhythms, rules; the relations of different hierarchical levels, between managers and subordinates and among colleagues; and the social and cultural aspects of the organization such as the performance, excellence, competition, and fidelity to the goals and ideals.

The establishment of the causal link or nexus between a particular individual or collective, potential or installed, health event, injury or illness, and a given working condition constitutes the basic condition for the implementation of Occupational Health actions. Through the establishment of these factors it is also possible to search for further improvements in the working conditions, aiming to assist in the planning and implementation of actions in the quality of life and health of the worker. Currently, the participation of the workers is seen as crucial in identifying health risks and in preparing proposals for their elimination or control, as well as in monitoring the implementation of the changes indicated. The re-planning of the work should be the result of collective and daily negotiations (Sato, Lacaz \& Bernardo, 2006).

\section{Firefighters and mental health/illness}

The requirements inherent to the profession often put the firefighter in borderline situations in terms of exposure to potentially traumatic stress events (Corneil, Beaton, Murphy, Johnson \& Pike, 1999). Therefore, it is not surprising that a significant percentage of firefighters develop mental disorders subsequent to traumatic experiences (Bennett et al., 2005; Centers for Disease Control and Prevention, 2006).

Firefighters were studied among the 40,000 professionals who flocked to aid the victims of the World Trade Center disaster, in the United States, on September 11, 2001 (Herbert et al., 2006). These workers were 
exposed to dust and toxic products, $69 \%$ of the respondents developed respiratory difficulties, with symptoms persisting more than $2 \frac{1}{2}$ years after the attacks. The main contribution of this study was the indication of the need for monitoring these professionals over the long-term for the possibility of developing other late effects, including malignant effects.

Studies regarding rescue professionals in natural disasters with large populations (Ursano, Fullerton, Benedek \& Hamaoka, 2007), emphasizing the attacks on the World Trade Center, Hurricane Katrina and the Asian Tsunami, indicate the need for further studies on the mental health of these workers, among them firefighters. The authors highlight the stress and the post-traumatic stress disorders that occur in this population, as being associated with clinical comorbidities suchas worry, fatigue, sleep and concentration disturbances, changes at work, interpersonal relationship difficulties, increased substance use, somatization and depression, and emotional symptoms, such as fear. Specifically in firefighters, rates of post-traumatic stress disorder ranging from $13 \%$ to $18 \%$ have been identified, characterized from 1 to 4 years after the events.

Chen et al. (2007) studied 410 firefighters in Kaohsiung, Taiwan, in a two stage survey, seeking to examine quality of life, prevalence of PTSD, depression and associated risk factors. In the first stage, two instruments were applied, the Short-Form Health Survey (SF-36) and the Disaster-Related Psychological Screening Test (DRPST), to access quality of life, likelihood of PTSD, likelihood of major depression and associated risk factors. In the second stage, the participants identified as having possible cases of illnesses were referred to psychiatrists who categorized them, according to the Diagnostic and Statistical Manual of Mental Disorders (DSM-IV) questionnaires, into a group diagnosed with major depression or PTSD, a subclinical group and a healthy group. The prevalence found was $5.4 \%$ for PTSD and $10.5 \%$ for major depression. The conclusion of the study suggested that firefighters should be encouraged to receive interventions from mental health professionals due to the risk of major depression or PTSD, and that this service should be offered by the fire departments.

Sangwoo, Driscoll, Bernard and West (2007) presented the results of a study conducted by the
National Institute for Occupational Safety and Health with 683 firefighters of New Orleans, 13 weeks after Hurricane Katrina devastated the coast of the United States in 2005. The Center for Epidemiologic Studies Depression Scale (CES-D) was used to define the symptoms consistent with major depression. The authors note that this instrument was not designed to evaluate depression in people who have experienced natural disasters considered traumatic, and highlight the need for new instruments with this specificity. Some physical symptoms were found to be factors associated with depression, among these respiratory disturbances and rashes were present. Dissatisfaction with the support of the supervisors was also associated with depression.

In Brazil, a study by Baptista, Morais, Carmo, Souza and Cunha (2005) with 101 firefighters in São Paulo, investigated the relationship between depressive symptoms, burnout and quality of life. This survey indicated a low prevalence of depression, as only 19\% of the professionals surveyed presented clinically significant symptoms, without configuring a diagnosis of depression. This study found a positive correlation between symptoms of depression and the dimensions of depersonalization and emotional exhaustion from burnout, and a negative correlation between depressive symptoms and quality of life. The authors also suggest that more studies need to be performed in order to develop more complex explanatory models regarding the relationship between these phenomena and to evaluate the risk factors that may cause these psychopathologies.

In the state of Minas Gerais, a mixed study was developed (Amato, Pavin Martins, Ronzani \& Batista, 2010), with 303 firefighters in the first stage and 37 participants in the second. The study aimed to evaluate mental health indicators and their related factors, considering gender differences. The data indicated a greater compromise of mental health of the female members of the department with regard to stress, depression, anxiety and general health risks, with the exception of alcohol, which was higher in the male members. The authors suggest that aspects related to physical strength and the status of being in a minority may be factors that influenced these results, 
and that these data could be useful in formulating future organizational interventions.

A Brazilian study conducted with 235 firefighters regarding key organizational factors that were associated with job stress was developed by Cardoso (2004). It identified that $55 \%$ of the firefighters studied presented symptoms of stress and found the major stress factors to be labor relations, work overload, and the lack of professional qualification and psychological support. Similarly, it was observed in another study (Natividade, 2009) that the risks of the profession, the organizational structure (hierarchy, discipline, standards) and the high requirement 'not to make mistakes' impact with the emergence of stress conditions in the work of the firefighters. The firefighters demonstrated the desire to discuss events that occur in their work environment to reduce this emotional distress, indicating that these discussions could be conducted by a specialist, preferably a psychologist.

A diagnosis developed by Monteiro et al. (2007) also indicated the need to support the professionals who are'always on alert'and work to save lives in natural disasters, automobile accidents, rescues, pedestrian accidents, and fires, among others. The lecture for the presentation of results 'almost' became a reflection group, demonstrating a latent need for psychological listening with these professionals. Ronzani et al. (2007) developed a program of Screening and Brief Intervention (TIB, Triagem de Interverção Breve) related to the use of alcohol that was applied with professional firefighters. They obtained good results and stressed the great need for effective work directed toward this problem to be performed with this public.

The aim of the present study was to investigate the working conditions and their association with the mental health of professional firefighters. The presence of symptoms of PTSD, depression, anxiety and alcohol use were evaluated, as well as aspects of the work activity that may be associated with the mental health conditions of these professionals.

\section{Method}

\section{Participants}

The study included 27 subjects (25 men and 2 440 women), aged between 23 and 50 years, with a mean age of 37.1 years and standard deviation of 7.9 years. The length of employment in the profession varied from 1 to 29 years (with a mean of 15.4 years and mean length of time in this unit of 9.5 years), $67 \%$ did not perform other work in addition to being a firefighter. The majority of the participants had completed high school education (70\%), were married (59\%) and had children (75\%), as shown in Table 1.

\section{Procedures and instruments}

First, a collective meeting was held to present the aims of the project and to invite interested parties to participate. At this meeting, after the presentation of the study and ethical explanations, a pilot study was conducted to adapt the instruments, with three of the interested individuals. After analyzing these data, the previously scheduled, collectiveand individual applications were carried out.

The self-report instruments applied in small groups were: the Beck Depression Inventory (BDI), the Beck Anxiety Inventory (BAl) and a questionnaire, developed for this study, regarding issues related to the work and the organization. The BDI consists of a selfreported scale of 21 multiple-choice items presented in the form of statements, and aims to measure the severity of depression in adults and adolescents (Beck \& Steer, 1993a; Cunha, 2001). The BAl is a self-report

\section{Table 1}

Descriptive characteristics of the sample

\begin{tabular}{lcc}
\hline Characteristics & $\mathrm{n}$ & $\%$ \\
\hline Male & 25 & 92.6 \\
Female & 2 & 7.4 \\
Incomplete high school education & 3 & 11.1 \\
Complete high school education & 19 & 70.4 \\
Incomplete higher education & 3 & 11.1 \\
Complete higher education & 2 & 7.4 \\
Has another job & 9 & 33.3 \\
Does not have another job & 18 & 66.7 \\
Single & 8 & 29.6 \\
Married & 16 & 59.3 \\
Separated/widowed & 3 & 11.1 \\
Does not have children & 7 & 25.9 \\
Has 1 child & 9 & 33.3 \\
Has 2 children & 4 & 14.8 \\
Has 3 children & 5 & 18.5 \\
Has 4 children & 2 & 7.1 \\
\hline
\end{tabular}


measure with 21 items in the form of descriptions of anxiety symptoms to be rated on a 4-point scale (Beck \& Steer, 1993b; Cunha, 2001). Both instruments have satisfactory psychometric qualities (Cunha 2001).

In the individual interviews the Alcohol Use Disorders Identification Test (AUDIT) and the Structured Clinical Interview for DSM-IV Post-traumatic Stress Disorder (SCID-PTSD) were applied. The AUDIT is composed of a 10 item scale used to estimate alcohol use and/or dependence (Lima et al. 2005). The clinical interview includes questions from the diagnostic criteria for Post-traumatic Stress Disorder and is composed of 17 items (symptoms) subdivided into: a) exposure to a traumatic event; b) re-experiencing the event; c) persistent avoidance; d) increased arousal; e) duration longer than one month; and f) clinically significant distress. The translation and adaptation to Portuguese of this instrument was performed Del-Ben, Zuardi, Vilela and Crippa (1998) and achieved satisfactory levels of validity.

\section{Ethical Procedures}

On the occasion of the collective meeting, the firefighters were invited to participate in the study and were clearly informed that their contribution to the study was voluntary and could be discontinued at any stage, without prejudice. In the first contact for data collection the Terms of Free Prior Informed Consent were completed and signed. All ethical care was taken to ensure the secrecy and confidentiality of the information and to preserve the identity of participants. The results of this research were made available to the participants and the ethical issues inherent in research with humans were observed, following Resolution no 196/96 of the Ministry of Health. This study was submitted to the Research Ethics Committee of the Universidade do Vale do Rio dos Sinos and approved under Protocol number CEP 06/043.

\section{Data Analysis}

The data obtained with the BDI, BAI, AUDIT and the structured interview for DSM-IV were collected and tabulated in the Statistical Package for the Social Sciences (version 13.0). A descriptive analysis of these data was carried out, in which measures of central tendency, dispersion and distribution properties for the variables of interest were evaluated. Clinical diagnoses related to the following variables were also collected and interpreted for each individual: depression, anxiety, alcohol use, and PTSD. Regarding the inferential analysis, correlational measurements between the variables of interest were performed.

The information collected in the Work Questionnaire were analyzed through the content analysis method (Bardin, 1994), which consisted of the analytical description of the manifest content and a subsequent interpretation. This was composed of three phases, which were: the pre-analysis, the exploration of the material, and the treatment of the results.

\section{Results and Discussion}

Responses given to the question regarding the reasons for choosing the profession were: the possibility of helping people: "What led me to this profession was the satisfaction in being able to help other people", the influence of the family: "I like the profession and know it well, because my father is also a firefighter", the admiration: "I have always had admiration for the work done by the fire department", stability and recognition of the profession: "The opportunity to pursue a profession with stability, for the recognition of the Firefighter by everyone, I like the military discipline, the opportunities to grow in the military career".

Regarding the working conditions, the results indicate the need for improvements: in the salary, which can be illustrated by the following statements: "The salary aspect, though not bad, could be better for the risk we run", "The wages are less than what would be fair, in comparison with similar public jobs ..."; the equipment used in the work: "Lack of personal safety equipment and already outdated materials" and in the training: "Lack of courses, instruction, having to work in various areas and not specializing in any of them". Personal valorization: "The recognition by a part of society regarding our performance and the personal satisfaction in saving the lives and possessions of other people"; and the time devoted to the family: "Now / spend more time with my family than before", were the main items cited as positive points of the profession and as the motivation to follow 
in this professional context, as well as the 'passion for the profession': "The satisfaction is in being able to provide a good service to other people and to the community in general", "Risking your life for the sake of others".

Considering the mental health aspects, it can be highlight that the evaluation of depression severity through the BDI showed: two subjects (7.4\%) with mild depression and two (7.4\%) with moderate depression. Regarding the classification of anxiety symptoms, as measured by the BAl, seven individuals presented mild anxiety (26.0\%), one moderate anxiety (3.7\%) and one severe anxiety (3.7\%).

Concerning the use of and/or dependence on alcohol, evaluated through the AUDIT six participants (22.2\%) presented indications of hazardous drinking and one $(3.7 \%)$ of harmful drinking, with probable dependence. It is worth mentioning here that the negative effects of alcohol use affect not only the health of individuals, but also their functional and occupational capacity (American Psychiatric Association, 2002). In the work activity, dependence can cause problems related to absenteeism or frequent lateness, difficulties in performing activities, unsafe acts that cause danger to life and to property of others or the company, relationship problems with colleagues, and insubordination to superiors (Lacerda, 2003).

In the diagnosis of Post Traumatic Stress Disorder, no subjects presented all the criteria that configure the disorder, i.e., a) exposure to a traumatic event; b) re-experiencing the event; c) persistent avoidance; d) increased arousal; e) duration longer than one month; and f) clinically significant distress. All the participants presented criteria $a-b$ and many of the respondents presented criterion c. In this case, two hypotheses can be proposed: the first would be that the group developed a subclinical Post-traumatic Stress Disorder, and the second that this group of workers created defensive strategies to avoid illness.

With regard to the events cited as traumatic, the majority of the participants described situations related to accidents and rescues with children. One of the statements referred to a child having been run over and demonstrates the rationalization that is needed to perform the service in the type of situation. The 442 firefighter described: "The girl was the same age as my daughter, her hair looked like my daughter's... . I had to use all my strength and training in that moment". In another striking report of a case, the firefighter recalled and quoted the words of a child victim of an accident who had lost both legs - 'uncle what happened to me?'.

The data also showed positive correlation between the number of children and the symptoms of depression $(r=0.65 ; p<0.001)$ and anxiety $(r=72$; $p<0.001)$, indicating that the higher the number of children, the greater the presence of symptoms associated with depression and anxiety - this suggests that children make these professionals more likely to feel emotional consequences in the work - "in one landslide a baby died as well as the mother who tried to protect the baby. I remembered my children".

Regarding the main aim to evaluate the association between the working conditions and the mental health of the firefighters, positive correlations were found between alcohol consumption and length of service ( $r=0.41 ; p=0.05)$, use of this substance and age $(r=0.40 ; p=0.05)$ and between depression and age $(r=0.39 ; p=0.05)$, these results indicate that the longer the length of service, the higher the alcohol consumption and frequency of symptoms of depression. This suggests emotional distress associated with the professional activity.

When asked about the facts/events that affected them most in their time in the profession, some cited specific cases, others only mentioned situations in general, however, all were unanimous in showing that, at the time of the occurrences, the emotions had to be suppressed. They also mentioned the need to be aware of and put into practice in the most correct and ethical way, all the resources and knowledge that they have to help the victim. The firefighters made themselves responsible for the results of their work and stressed that were trained not to lose control and not to let themselves become shocked in these situations - "We are trained to act in situations in which a person that does not have the emotional control of the firefighter would never act". In this sense, Dejours (1999) emphasized that the state of normality should not be confused with the state of health of the worker. Although, on one hand, normality can reflect a healthy balance in people, it can also be a symptom of a pathological state, i.e., there is a 
delicate balance between the destabilizing forces of the subjects and their efforts and those of the groups, in order to stay productive at the cost of much distress. The distress is often not manifested because the subjects actively seek to protect and defend themselves. For this they use group and/or individual defense mechanisms and defensive strategies.

Toassi, Stolf and Oliveira (2006) highlighted in a previous study that firefighters often repress the feeling at the expense of the procedures and guidelines for action that they must follow, as they must remain always vigilant, indicating in their study that, due to this, there is no space for emotion and feelings to surface. These professionals mentioned that they seek, after the occurrence of a stressful call, to find 'escape valves' to be able to express their feelings, with this also possibly related to alcohol use.

In the firefighters studied, particular ways of dealing with issues of risk and/or death were observed. For example, some individuals reported that they prefer not to talk about their work routines with their family, while others found support within the family. It is known that these professionals receive training, in which they learn how to act and how to operate the material resources necessary for their functions, among other things. Even so, there is the account of the participants that they are "always in a state of alert" and that, even though the occurrences are repeated, each victim is unique and each case is solved differently, implying constant decision making and assumption of the resulting risks. Often it is not possible to follow the prescribed procedures.

\section{Final Considerations}

In this study we can reflect that, although we found a low incidence of diagnoses of the pathologies studied, it can be seen that several symptoms were presented that denote mental distress, and that these indications appear more in the firefighters with longer career durations and in those with children. It should also be noted that these results are specific to the group studied and cannot be generalized for this category. The results presented in this study highlight the need for psychological listening and support, as well as for psychosocial interventions aimed at this group of workers. This issue suggested that firefighters should be encouraged to receive interventions from mental health professionals, due to the risk of mental illness and psychological distress associated with the profession.

\section{References}

Amato, T. C., Pavin T., Martins L. F., Ronzani T. M., \& Batista, A. (2010). Trabalho, gênero e saúde mental: uma pesquisa quantitativa e qualitativa entre bombeiros. Cadernos de Psicologia Social e do Trabalho, 13(1), 103-118.

American Psychiatric Association. (2002). Manual diagnóstico e estatístico de transtornos mentais (4a ed.). Porto Alegre: Artmed.

Baptista, M. N., Morais, P. R., Carmo, N. C., Souza, G. O., \& Cunha, A. F. (2005). Avaliação de depressão, síndrome de Burnout e qualidade de vida em bombeiros. Psicologia Argumento, 23(42), 47-54.

Bardin, L. (1994). Análise de conteúdo. Lisboa: Edições 70.

Beck, A. T., \& Steer, R. A. (1993a). Beck depression inventory: Manual. San Antonio: Psychological Corporation.

Beck, A. T., \& Steer, R. A. (1993b). Beck anxiety inventory: Manual. San Antonio: Psychological Corporation.

Bennett, P., Williams, Y., Page, N., Hood, K., Woollard, M., \& Vetter, N. (2005). Associations between organizational and incident factors and emotional distress in emergency ambulance personnel. British Journal of Clinical Psychology, 44(2), 215-226.

Cardoso, L. A. (2004). Influências dos fatores organizacionais no estresse de profissionais bombeiros (Dissertação de mestrado não-publicada). Programa de Pós-Graduação em Psicologia, Universidade Federal de Santa Catarina.

Centers for Disease Control and Prevention. (2006). Health hazard evaluation of police officers and firefighters after Hurricane Katrina: New Orleans, Louisiana, October 17-28 and November 30-December 5, 2005. Morbidity and Mortality Weekly Report, 55(16), 456-458.

Codo, W., Soratto, L., \& Vasques-Menezes, I. (2004). Saúde mental e trabalho. In J. C. Zanelli, J. E. Borges-Andrade \& A. V. B. Bastos (Orgs.), Psicologia, organizações e trabalho no Brasil (pp.276-299). Porto Alegre: Artmed.

Chen, Y. S., Chen, M. C., Chou, F. H. C., Sun, F. C., Chen, P. C., \& Tsai, K. Y. (2007). The relationship between quality of life and posttraumatic stress disorder or major depression for firefighters in Kaohsiung, Taiwan. Quality Life Res, 16(8), 1289-1297.

Corneil, W., Beaton, R., Murphy, S., Johnson C., \& Pike, K. (1999). Exposure to traumatic incidents and prevalence of posttraumatic estresse symptomatology in urban firefighters in two countries. Journal ofOccupational Health Psychology, 4(2), 131-141.

Cunha, J. A. (2001). Manual da versão em português das Escalas Beck. São Paulo: Casa do Psicólogo. 
Del-Ben, C. M., Zuardi, A. W., Vilela, J. A. A., \& Crippa, J. A. S. (1998). Entrevista clínica estruturada para o DSM-IV: transtornos do eixo I (SCID-I) - versão clínica. Ribeirão Preto: USP.

Dejours, C. (1999). A banalização da injustiça social. Rio de Janeiro: FGV.

Herbert, R., Moline, J., Skloot, G., Metzger, K., Baron, S., Luft, B., et al. (2006). The World Trade Center disaster and the health of workers: Five-year assessment of a unique medical screening program. Environmental Health Perspectives, 114(12), 1853-1858.

Lacerda, A. L. T. (2003). Álcool e local de trabalho. In L. A. M. Guimarães \& S. Grubits (Orgs.), Saúde mental e trabalho (Vol. 1, pp.17-33). São Paulo: Casa do Psicólogo.

Lima, C. T., Freire, A. C., Silva, A. P. B., Teixeira, R. M., Farrel, M., \& Price, M. (2005). Concurrent and construct validity of the AUDIT in an urban Brazilian sample. Alcohol and Alcoholism, 40(6), 584-589.

Lima, M. E. A. (2003). A polêmica em torno do nexo causal entre distúrbio mental e trabalho. Psicologia em Revista, 10(14), 82-91.

Mendes, A. M. (2007). Da psicodinâmica à psicopatologia do trabalho. In A. M. Mendes (Org.), Psicodinâmica do trabalho: teoria, método e pesquisas (pp.29-47). São Paulo: Casa do Psicólogo.

Mendes, A. M., \& Morrone, C. F. (2002). Vivências de prazer: sofrimento e saúde psíquica no trabalho: trajetória conceitual e empírica. In A. M. Mendes, L. O. Borges \& M. C. Ferreira (Orgs.), Trabalho em transição, saúde em risco (pp.25-42). Brasília: UnB.

Minayo-Gomez, C., \& Thedim-Costa, S. M. F. T. (1997). A construção do campo da saúde do trabalhador: percurso e dilemas. Cadernos de Saúde Pública, 13(2), 21-32.
Monteiro, J. K., Pesenti, C., Maus, D., Bottega, D., Machado R. F., \& Carniel B. L. (2007). Bombeiros: um olhar sobre a qualidade de vida no trabalho. Psicologia: Ciência e Profissão, 27(3), 554-565.

Natividade, M. R. (2009). Vidas em risco: a identidade profissional dos bombeiros militares. Psicologia \& Sociedade, 21(3), 411-420.

Ronzani, T. M., Rodrigues, T. P., Batista, A. G., Lourenço, L. M., \&Formigoni, M. L. O. S. (2007). Estratégias de rastreamento e intervenções breves para problemas relacionados ao abuso de álcool entre bombeiros. Estudos de Psicologia (Natal), 12(3), 285-290.

Sato, L., Lacaz, F., \& Bernardo, M. (2006). Psicologia e saúde do trabalhador: práticas e investigações na saúde pública de São Paulo. Estudos de Psicologia (Natal), 11(3), 281-288.

Sangwoo, T., Driscoll, R., Bernard, B., \& West, C. (2007). Depressive symptoms among firefighters and related factors after the response to Hurricane Katrina. Journal of Urban Health:Bulletin of the New York Academy of Medicine, 84(2), 153-161.

Toassi, A. J., Stolf, M. C., \& Oliveira, M. R. (2006). Inserção tecnológica no trabalho: etnografia das significações profissionais de bombeiros. Psicologia: Ciência e Profissão, 26(2), 280-293.

Ursano, R. J., Fullerton, C. S., Benedek, D. M., \&Hamaoka, D. A. (2007). Hurricane Katrina: Disasters teach us and we must learn. Academic Psychiatry, 31(3), 180-182.

Received on: 19/8/2011

Approved on: 3/11/2011 